\title{
Organchlorine Insecticides and Polychlorinated Biphenyls Residues in Soil and Water Samples Collected From El-Gabal El-Akhdar, Libya
}

\author{
Saad A. S. A. ${ }^{1}$, Elsayed H. M. Tayeb ${ }^{1}$, Laila A. Mohamed ${ }^{2}$ and S. M. I. Hassan ${ }^{1}$
}

\begin{abstract}
Organochlorine insecticides (OCIs) such as HCH $(\alpha, \beta$ and $\gamma$ Hexachlorocyclohexane), DDT (dichloro-diphenyltrichloroethane) and its metabolites, aldrin, dieldrin and endrin were determined in soil and groundwater samples collected from different locations at El-Gabal (AlJabal) ElAkhdar, Libya during summer (August 2014) and winter (January 2015) seasons. In addition, the residues of PCBs (polychlorinated biphenyls) species were inspected and determined. Generally, the calculated $\Sigma$ DDT of the detected residues of DDT family members that have been detected in summer were higher (with a maximum of $10.110 \mu \mathrm{g} / \mathrm{l})$ than those detected in soil samples of winter season (a maximum of $4.547 \mu \mathrm{g} / \mathrm{l}$ ). The results demonstrated the absence of endrin in the majority of the study sites. The results indicated the presence of about seven species of PCBs in the soil samples at different sites (PCB28, PCB52, PCB101, PCB118, PCB135, PCB138 and $\mathrm{PCB180}$ ). It was observed that $\mathrm{OCI}$ residues were detected in ground water samples during summer season at few sampling sites but they were almost absent during winter season. Water samples analysis in winter showed that there were only four sites that have been found to contain members of DDT isomers.. The residues of endrin were found in high levels in both water samples of summer $(2.09$ $\mu \mathrm{g} / \mathrm{l})$ and winter $(1.25 \mu \mathrm{g} / \mathrm{l})$ as compared with OCIs. Meanwhile, $o, p$ DDE $(0.9155 \mu \mathrm{g} / \mathrm{l})$ and $\alpha \mathrm{HCH}(1.3230 \mu \mathrm{g} / \mathrm{l})$ were detected at high concentrations during winter season in water samples. In winter, the results indicated that the highest concentration of $\mathrm{PCB}$ species was detected in water samples collected in summer and was found in Qandula location (PCB 101= 7.239 $\mu \mathrm{g} / \mathrm{l}$ ), while the lowest mean of concentration was presented in the location of $\mathrm{Al}$ Abraq where PCB 28 reached a concentration of $0.062 \mu \mathrm{g} / \mathrm{l}$

Keywords: Organochlorine insecticides (OCIs), Polychlorinated biphenyls (PCBs), Residue analysis, ElGabal El-Akhdar, Libya, irrigation underground water, soil
\end{abstract}

\section{INTRODUCTION}

In Libya, chlorinated hydrocarbons and other pesticides are being used for controlling pests of an agriculture and public health importance since there were no regulations or recommendations of pesticides application. The organochlorine compounds are broad spectrum insecticides, and were the most widely used in many countries for agricultural purposes and control of mosquitoes (Bouman, 2004; Blaso et al., 2005).
Organochlorine insecticides are very stable compounds and it has been cited that the degradation of dichlorodiphenyl-trichloroethane (DDT) in soil ranges from 4 to 30 years, while other chlorinated are stable for many years after application, due to a high resistance to chemical and biological degradations (Afful et al., 2010). Organochlorine insecticides (OCIs) have been dispersed ubiquitously in the environment (Yi-Fan et al., 1996). When applied on a field, they can meet a variety of fates: some may be lost to the atmosphere through volatilization and transported long distances from their sites of application; others are carried away by surface runoff or photo-degraded by sunlight. When entering into the soil, pesticides may be taken up by plants or degraded; but they may also be transported through the unsaturated zone to ground-waters or via drains, reach surface water bodies. Consequently, considerable levels of OCIs have been detected in different components of human environment such as air, water, soil, plants and animals (Patton et al., 1991). Calamari and Naeve (1994) concluded that the concentrations of pesticides found in various aquatic compartments, with few exceptions are lower than in other parts of the world, in particular in developed countries which have a longer history of high pesticide consumption and intense use.

OCIs are now less widely used than previously because of a number of disadvantages including environmental persistence, bioaccumulation and their toxic action upon the nervous systems (Hellwell, 1988). Also their entry into an ecosystem adversely affects many non-target organisms including fish and birds (Ayas et al., 1997). Their effects may be acute, resulting in mass mortality or chronic, involving changes in survival growth and reproduction (Kocan and Landolt, 1989). They and their degradation products are more toxic for animals (Barlas, 1997) and play important role in the population declines of water birds (Fox et al., 1991). Contamination of water bodies by pesticide residues has been an issue of serious concerns due to the health risks associated with them (Golfinopoulos et al., 2003). It is well known that DDT was listed by the Stockholm Convention as 1 of 12 persistent organic pollutants (POPs) in 2004 (Zhu et al., 2005). Organochlorines such as chlorinated insecticides and

${ }^{1}$ Plant Protection Dept., Faculty of Agric, Alex Univ., Egypt. ${ }^{2}$ Marine Chemistry Unit, National Institute of Oceanography and Fisheries, Kayet Bay, Alexandria, Egypt.

Received December 06,2017, Accepted December 30, 2017 
polychlorinated biphenyls (PCBs) represent important groups of POPs (persistent organic pollutants), which have caused worldwide concern as toxic environmental contaminants (Covacia et al., 2005).

The term polychlorinated biphenyls, or PCBs, refers to a class of synthetic organic chemicals that are, to a large degree, chemically inert. PCBs have been widely used as additives to oils in electrical equipment, hydraulic machinery, and other applications where chemical stability has been required for safety, operation, or durability. Although the chemical stability of many PCBs has been a benefit from the standpoint of commercial use, it has created an environmental problem because it translates into extreme persistence when the PCBs are eventually released into the environment. In fact, PCBs are among the most widespread environmental pollutants, having been detected in virtually all environmental media (indoor and outdoor air, surface and ground water, soil, and

Table 1. Locations of soil and water samples collected from different sites at El-Gabal El-Akhdar area in Libya

\begin{tabular}{cccccc}
\hline Site No. & Location & Site No. & Location & Site No. & Location \\
\hline 1 & Qandula & 6 & Qasr-Libya & 11 & Masah \\
2 & Qandula & 7 & Al-Haniyah & 12 & Masah \\
3 & Marawah & 8 & Al-Haniyah & 13 & Al-Abraq \\
4 & Marawah & 9 & Al-Wasita & 14 & Al Abraq \\
5 & Qasr-Libya & 10 & Al-Wasita & & \\
\hline
\end{tabular}

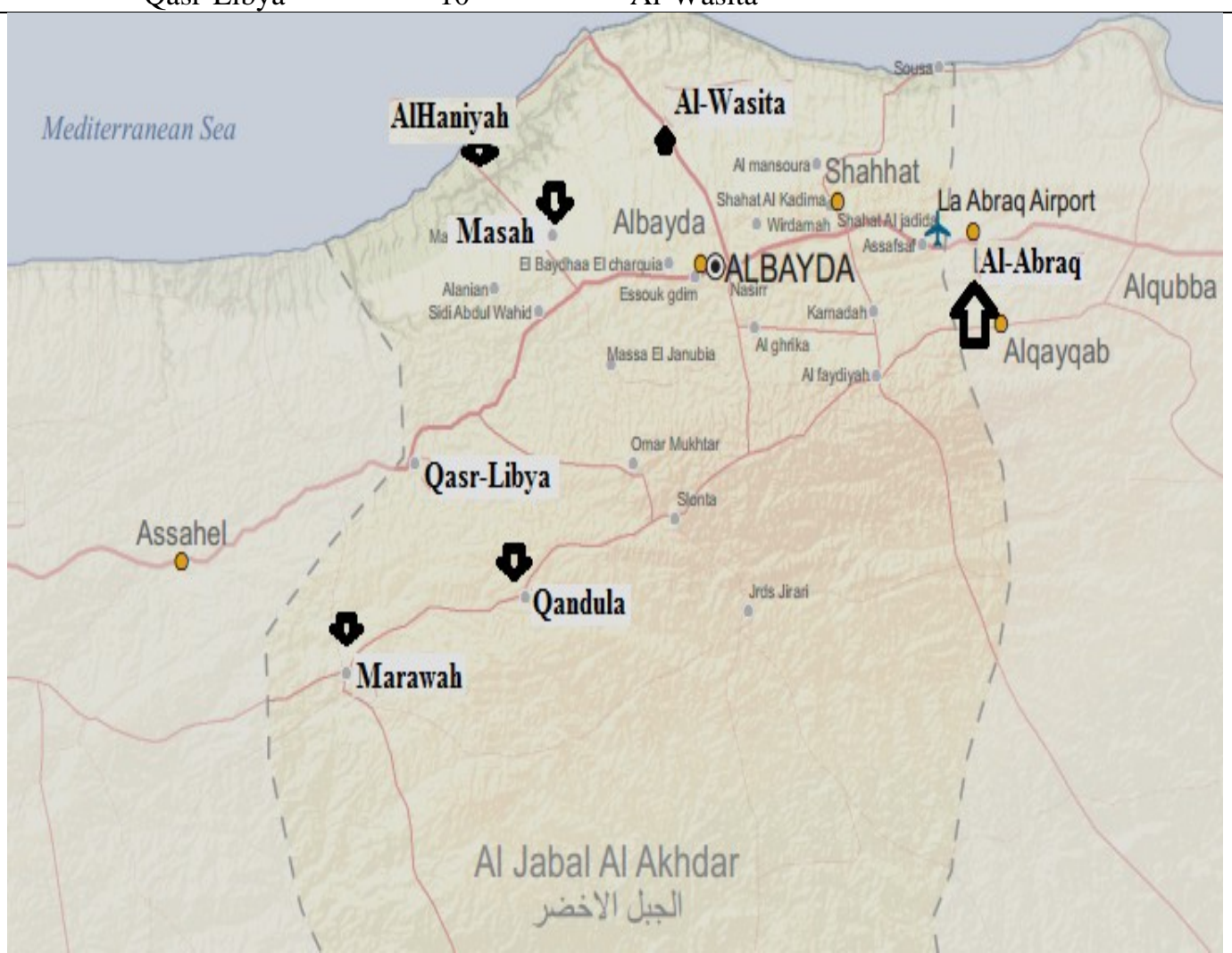

Figure 1. Different locations of study at El-Gabal El-Akhdar, Libya 


\section{A-Water samples}

Water samples (3 liters/site) were collected from groundwater wells that are being used for irrigation at fourteen sites (Table1), stored at 4 ? and transported to the laboratory for the analysis procedures (OCIs and PCBs residue determination).

\section{B- Soil samples}

Soil samples $(2 \mathrm{~kg} / \mathrm{site})$ were collected from the different selected locations of study using a stainlesssteel grab sampler. Samples were taken from each location from the top $3 \mathrm{~cm}$ area, and then they were scooped into pre-cleaned wide-mouth glass bottles, placed in ice box, transported to the laboratory and stored at -20 ? C until analysis. OCIs and PCBs were determined within the collected soil samples.

\section{Residues determination}

\section{A-Residues extraction}

For water samples, liquid-liquid extraction $(1000 \mathrm{ml}$ of water sample+ $100 \mathrm{ml}$ dichloromethane) was followed by gas chromatographic analysis (USEPA, 1980) to determine OCIs and PCBs residue. Extraction from soil was done and modified from that method described by USEPA (1996). Each sample (30g) was then thoroughly mixed with $90 \mathrm{~g}$ of anhydrous sodium sulfate. The soil sample was then extracted with $250 \mathrm{ml}$ (1:1) of $\mathrm{n}$-hexane:dichloromethane for $8 \mathrm{hrs}$ in a Soxhlet apparatus cycling 5-6 times/ h (Sporring et al., 2005). The extracts were then combined and desulfurized through activated copper powder and then concentrated to a few milliliters.

\section{B-Identification and quantification of OCIs and PCBs residues}

Identification and quantification of pesticide residues were done by using Gas Chromatograph-Mass Spectrometer, GCMS (Thermo Scientific Company Trace DSQ II MS) on fused-silica capillary column (Thermo TR-35 MS [3.0m* $0.25 \mathrm{~mm}$ ] filled with $35 \%$ phenyl polyphenylene-siloxane (stationary phase). Organochlorine insecticides were quantified from individually resolved peak areas with the corresponding peak areas of the standards. Helium was used as carrier gas at flow rate of $2 \mathrm{ml} / \mathrm{min}$. The temperature was programmed from $90-140^{\circ} \mathrm{C}$ with a rate of $5^{\circ} \mathrm{C} / \mathrm{min}$, then holed at $140{ }^{\circ} \mathrm{C}$ for $1 \mathrm{~min}$, and from $140-250^{\circ} \mathrm{C}$ with a rate of $3^{\circ} \mathrm{C} / \mathrm{min}$ and was holed at $250{ }^{\circ} \mathrm{C}$ for $1 \mathrm{~min}$, and from $250-300^{\circ} \mathrm{C}$ with a rate of $20^{\circ} \mathrm{C} / \mathrm{min}$ and was holed at $300^{\circ} \mathrm{C}$ for $1 \mathrm{~min}$. The injector, ion source, and detector temperatures were set at $280^{\circ} \mathrm{C}$, $250^{\circ} \mathrm{C}$ and $310^{\circ} \mathrm{C}$, respectively. Three microliters $(3 \mu \mathrm{l})$ of each sample was injected in the split less mode and the purge time was $1 \mathrm{~min}$. Retention time and peak areas were compared with the standards. The analysis process of the collected samples of irrigation water (ground water) and soil was carried out at the Central Lab. Unit of the National Institute of Oceanography and Fisheries, Alexandria, Egypt.

\section{Statistical analysis}

Data of the present investigation were subjected to the analysis of variance (ANOVA) using "F Test" following the randomized complete block design (RCBD), with three replicates for each treatment. The least significant differences (L.S.D) at the $0.05 \leq$ level were determined according to computer program (COSTAT software, 1988).

\section{RESULTS AND DISCUSSION \\ A-Residues of OCIs and PCBsin soil samples}

Although certain persistent pesticides have been banned for years, the results of the conducted study indicates the presence of chlorinated insecticide residues in some selected sites at different levels depending on the type of insecticide, the nature of region in addition to the season and date of sampling. However, OCIs residues were not detected and they were totally absent in some soil samples (sites 8, 10 and 11). Tables 2 and 3 show the analytical determination of the residues of DDT family representing DDT and its metabolites (products) (DDE and DDD), as well as the residues of $\alpha, \beta, \gamma$ isomers of $\mathrm{HCH}$ in addition to the residues of three other insecticides (aldrin, dieldrin and endrin) inspected in irrigation water and soil samples at El-Gabal El-Akhdar area, Libya. The differences in the concentrations of these insecticide residues in the soil samples may be due to the substantial inter-farm variation, the intensive use of pesticide and the rate of application as well as the differences in their degradation rate (Owusu-Boateng and Amuzu, 2013).

Results showed significant increase $(\mathrm{p} \leq 0.01)$ in site $6(\alpha-\mathrm{HCH})$, sites $1,3,4,5,6,9,13$ and14 ( $p, p$ DDE), sites 6, 9 and14 ( $p, p$ DDD) and site 9 (endrin) during summer season. During winter season, there were also significant increases in site 2 ( $p, p$ DDE), site 13 (o,p $\mathrm{DDE}$ ), site 14, (dieldrin) and site $5 \& 9$ (endrin) .Concentrations of $\Sigma \mathrm{HCH}$ and $\Sigma$ DDT were calculated by summing the three $\mathrm{HCH}$ isomers $(\alpha, \beta$ and $\gamma$ ) and six DDT members (metabolites), in respect.

\section{HCH isomers}

The concentrations of $\mathrm{HCH}$ isomers that have been found in the soil samples during summer season showed variations from one region to another, where the highest concentrations were found in Qaser-Libya location (site 6) $(\beta \mathrm{HCH} 1.537 \mu \mathrm{g} / \mathrm{l})$ followed by the region of Marawah (site 3) $(\beta \mathrm{HCH} 0.405 \mu \mathrm{g} / \mathrm{l})$ and then the 
location of Al-Wasita (site 9) ( $\beta$ HCH $0.345 \mu \mathrm{g} / \mathrm{l}$ ) (Table 2). The results of soil samples analysis in winter showed that the highest concentrations of $\mathrm{HCH}$ isomers were found in the Al-Haniyaha location (site 7) $(\beta$ $\mathrm{HCH}=4.610 \mu \mathrm{g} / \mathrm{l})$ followed by Al-Abraq (site 14) $(\beta$ $\mathrm{HCH} 0.626 \mu \mathrm{g} / \mathrm{l}$ ) and Al-Wasita (site 9) $(\alpha \mathrm{HCH}$ $0.251 \mu \mathrm{g} / \mathrm{l}$ ) (Table 3).

It was noticed that $\mathrm{HCHs}$ concentrations were less and lower than those of DDTs'. This might be due to the different physicochemical and biological properties of these compounds (Tang et al., 2007).Therefore, HCHs concentrations were found to be low under the different seasons and locations conditions and this might be also due to less recent input of lindane (Gammexane ${ }^{\circledR}$ ) $(\mathrm{HCH})$. This could be also explained by the large amount of historical use of DDT in such specific farms (sites).

\section{DDT family (metabolites)}

Generally, the calculated $\Sigma$ DDT of the detected residues of DDT family members that have been detected in summer were higher (with a maximum of $10.110 \mu \mathrm{g} / \mathrm{l})$ than those detected in soil samples of winter season (a maximum of $4.547 \mu \mathrm{g} / \mathrm{l}$ ). It was found that the locations of Qasr-Libya (site 6) $(10.11 \mu \mathrm{g} / \mathrm{l})$ and Al-Wasita (site 9) $(8.67 \mu \mathrm{g} / \mathrm{l})$ and Al-Abraq (sites 13 and14) (10.01 and $9.28 \mu \mathrm{g} / \mathrm{l})$ contained the highest residues of DDT family members. In those soil samples of summer season, it was found that both isomers of $p, p$ DDT and $o, p$ DDT were recorded as very low concentrations in the all detected sites and sometimes they were totally absent. The $p, p$ DDE isomer was found as a high concentration as $6.738 \mu \mathrm{g} / 1(\mu \mathrm{g} / \mathrm{l})$ (site 9 ), while the $o, p$ DDE isomer was high in site 13 $(4.537 \mu \mathrm{g} / 1)$. Meanwhile, the $p, p$ DDD isomer was higher in both sites 6 and 14 (6.121 and $6.642 \mathrm{ppb}$, respectively)(Table 2).

The soil samples analyzed in winter season showed that the highest concentration of DDT isomers was found in the location of Al-Abraq (site 13) where $p, p$ DDE and $o, p$ DDE were as high as 2.098 and 2.184 $\mu \mathrm{g} / 1$, in respect (Table 3 ).

$\Sigma$ DDT residues were lower in those samples of winter as compared with summer samples. $\Sigma$ DDT was the highest $(4.55 \mu \mathrm{g} / \mathrm{l})$ in Al-Abraq (site 13) as determined in winter soil samples (Table 3 ). The presence of the DDT analogs (metabolites) indicated deterioration of DDT compound in the environment due to the decay of the solar radiation or metabolism by living organisms (Hooper et al., 1997 and Salem et al., 2014). The presented results also indicated that such chlorinated insecticides (OCIs), especially DDT, were used during past years in these selected location in ElGabal El-Akhdar, Libya for study and therefore OCIs still detected with their metabolites (isomers). This can be related due to their low solubility and these results are in agreement with those reported by Dubus et al. (2000).

\section{Aldrin, dieldrin and endrin residues}

Residues of the insecticide aldrin were found in soil samples collected in the summer season where the highest mean concentration was detected in $\mathrm{Al}$ Wasita location (site 9) $(0.582 \mu \mathrm{g} / \mathrm{l})$, followed by that determined at the Al- Haniyah location (site 7) (0.288 $\mu \mathrm{g} / \mathrm{l})$. The results of the soil samples collected in the winter season revealed that aldrin residues were found in sites No. 3, 7, 9 and 14 and the highest mean concentration $(0.781 \mu \mathrm{g} / \mathrm{l})$ was detected in the location of Al-Wasita (site 9), while the lowest mean concentration of $0.121 \mu \mathrm{g} / \mathrm{l}$ was found in Marawah location (site 3).

Some areas of study where the soil samples were collected from them during the summer season were found to contain residues of dieldrin where the highest mean concentration of residues was found in $\mathrm{Al} \mathrm{Al-}$ Abraq location (site 13) $(0.523 \mu \mathrm{g} / \mathrm{l})$ and the lowest mean concentration of residues of that compound was found in Qasr-Libya location (site 6) (0.045 $\mu \mathrm{g} / \mathrm{l})$ (Table 2).

In winter, the results of the soil samples analysis indicated that Al-Abraq location (site 14) contained the highest mean concentration of dieldrin $(1.193 \mu \mathrm{g} / \mathrm{l})$, while the lowest mean concentration was found in Marawah location (site 4) $(0.039 \mu \mathrm{g} / \mathrm{l})$. The results demonstrated the absence of endrin in the majority of the study sites which has been proved through the analysis of these soil samples collected in summer and endrin was found only in sites 5, 6 and 9 sites. At AlWasita location (site 9), the results demonstrated the highest mean concentration $(3.130 \mu \mathrm{g} / \mathrm{l})$ of endrin, while the lowest mean concentration of its residues $(0.249 \mu \mathrm{g} / \mathrm{l})$ was detected in Qasr-Libya location (site 5) during summer. Some soil samples that were collected in winter contained endrin and the highest mean concentration was detected in Qasr-Libya location (site 5) $(2.881 \mu \mathrm{g} / \mathrm{l})$, while the lowest mean concentration was found in Al-Abraq location (site 13) (0.043 $\mu \mathrm{g} / \mathrm{l})$.

The accumulation of aldrin in soil samples analyzed during the present study was probably originated from its historical use where different formulations of organochlorine insecticides were extensively used in the past (Mawussi, 2008). Dieldrin was detected at some sites and this might be due to the little agricultural 


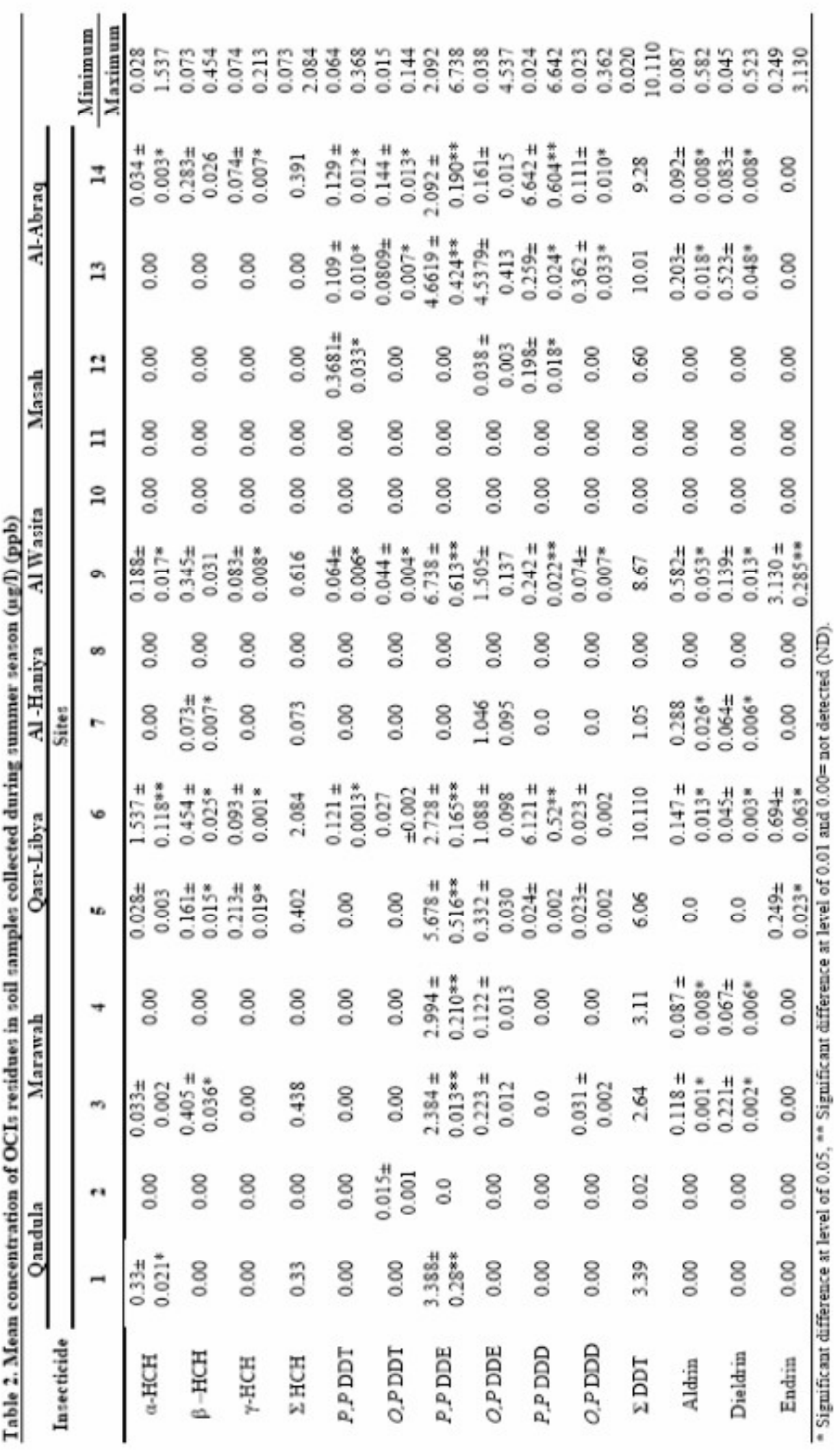




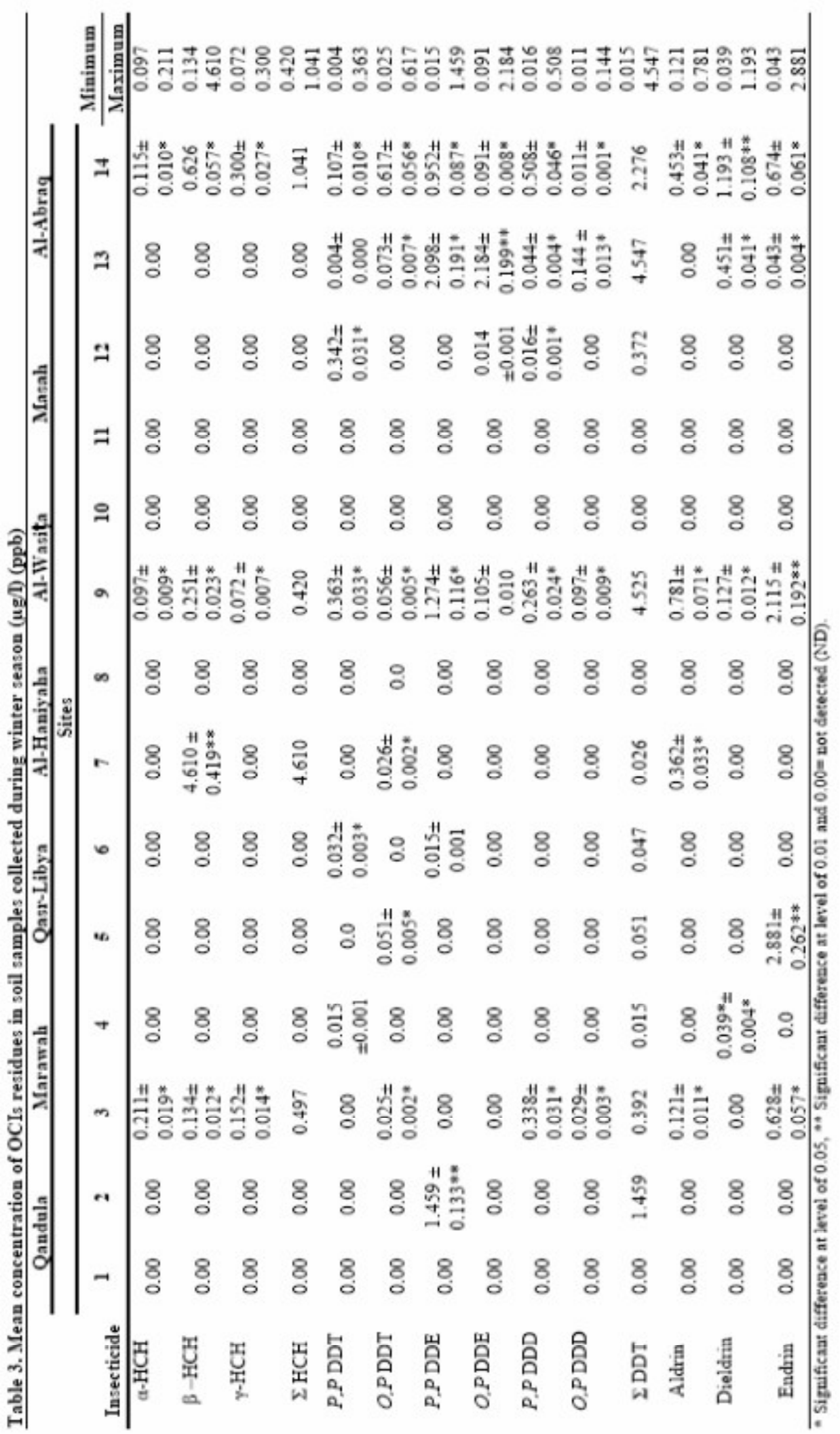


cultivation that has been practiced in the past or possibly due to little use of dieldrin at these sites in past. The highest concentrations of aldrin, dieldrin and dieldrin were found at the sampling site No.14 (AlAbraq) during both seasons and this can be attributed to the intensive production of crops and the application of such chlorinated insecticides in this location. Concentrations and patterns of OCIs distribution could be influenced by the chemical and the physical properties of such OCIs that have been applied under certain environmental conditions (Montenegro et al., 1998).

The obtained results showed that soil samples contained DDT, DDD, DDE, HCH isomers, aldrin, dieldrin and endrin. The concentrations of the compounds were mostly found in the surface of soil samples. The results of this study showed that there is a variation in the levels of chlorinated insecticides residue from season to another and from one location to another. Kanatharana et al. (1994), El-Bouraie et al. (2011) and Mahugija et al. (2014) found that the concentration of the detected compounds varied according to the location and the samples collection period.

\section{PCBs residues}

Tables (4 and 5) demonstrated the results of analysis of the soil samples that have been collected in the summer (August/2014) and winter (January/2015) seasons. The PCBs species were detected in these samples collected from different sites of El-Gabal ElAkhdar area, Libya. The PCBs detection is a very important process for the assessment of a contaminant or pollution problem. Podlesakova et al. (1997) reported that PCBs monitoring was conducted in the United Kingdom, USA, Canada, Japan, and Sweden and it had a valuable environmental benefits.

The detection of PCB28 at site $13(1.733 \mu \mathrm{g} / \mathrm{l})$, PCB52 at sites 3, 4, 5, 6, 7and 9 (with a maximum of $15.089 \mu \mathrm{g} / \mathrm{l}$ ), PCB118 at sites 7 and14 (with a maximum of $10.000 \mu \mathrm{g} / \mathrm{l}$ ) and PCB 138 at site 14 $(4.610 \mu \mathrm{g} / \mathrm{l})$ showed a high significant increase during summer season as compared with the those samples of winter.

It was found that the sites 6 and 9 contained many PCB species (PCB28, PCB52, PCB101, PCB11, PCB135, PCB138 and PCB180). The highest mean concentration of PCB $52(15.089 \mu \mathrm{g} / 1)$ was detected at Al-Wasita area (site 9), while Masah area showed the lowest concentration at site $12(\mathrm{PCB} 135=0.037 \mu \mathrm{g}$ /l) as shown in Table 4. In winter soil samples, it was found that Qasr - Libya location (site 6) contained 7 PCB species (PCB28, PCB52, PCB101, PCB118,
PCB135, PCB138and PCB180) and the highest mean concentration was that detected in Qasr -Libya location (site 6) $(\mathrm{PCB} 118=8.966 \mu \mathrm{g} / \mathrm{l})$, while the lowest mean concentration was that detected in Al-Wasita location (site 9) $(\mathrm{PCB} 135=0.017 \mu \mathrm{g} / \mathrm{l})$ as shown in Table 5.

The results of laboratory analysis indicated the presence of about seven species of PCBs in the soil samples at different sites (PCB28, PCB52, PCB101, PCB118, PCB135, PCB138 and PCB180). The results of this study are consistent with the results of previous studies, which monitored PCB species and detected the existence of about seven of the PCB in all parts of the world, particularly in samples such as soil (Covaci et al., 2002; Pawlak and Laamanen, 2010; Duc and Viet, 2013; Hassan et al., 2013).

The results also showed that PCB residues existed in the samples collected in summer more than those samples collected in winter, either in species number or concentration. The present results are in agreement with those reported by Tasdemir (2012) who found that the sampling date (spring or/and summer) had an effect on the PCB content in the soil, which may be increase in high soil temperature.

\section{B- Residues of OCIs and PCBs in water samples}

The mean concentrations of OCIs residues that have been detected in ground water samples in summer and winter seasons are demonstrated in Tables 6 and 7. It was observed that organochlorine insecticides residues were detected during summer season at few sampling sites but they were almost absent during winter season, although these insecticides might be used in agricultural purposes (insect control). This could be attributed to the process by which soil character during dry season promote adsorption of insecticides to soil particles (Leong et al., 2007; Shivani et al., 2012; Solomon, 2016) and therefore, water samples collected for the present study appeared to be free of OCIs. This can be attributed also to the fast rate of degradation that was accelerated through the variation of climatic conditions during summer in the area of study and these results are in agreement with those of El- Bouraie et al. (2011).

\section{HCH isomers}

The analysis of water samples collected during summer season (Table 6) showed that $\alpha \mathrm{HCH}$ was detected only at Qandula location (site 1) $(1.32 \mu \mathrm{g} / \mathrm{l}$ ) and Qasr-Libya $(0.12 \mu \mathrm{g} / \mathrm{l})$. $\beta \mathrm{HCH}$ was totally absent where it was not detected in the all detected water samples collected from the selected different locations of El-Gabal El-Akhdar, Libya. Meanwhile, $\gamma \mathrm{HCH}$ was only detected in Al-Abraq location (site 13) at a low concentration of $0.76 \mu \mathrm{g} / \mathrm{l}$. Therefore, $\Sigma \mathrm{HCH}$ was present in Qandula location (site 1), (1.323 $\mu \mathrm{g} / \mathrm{l})$, 


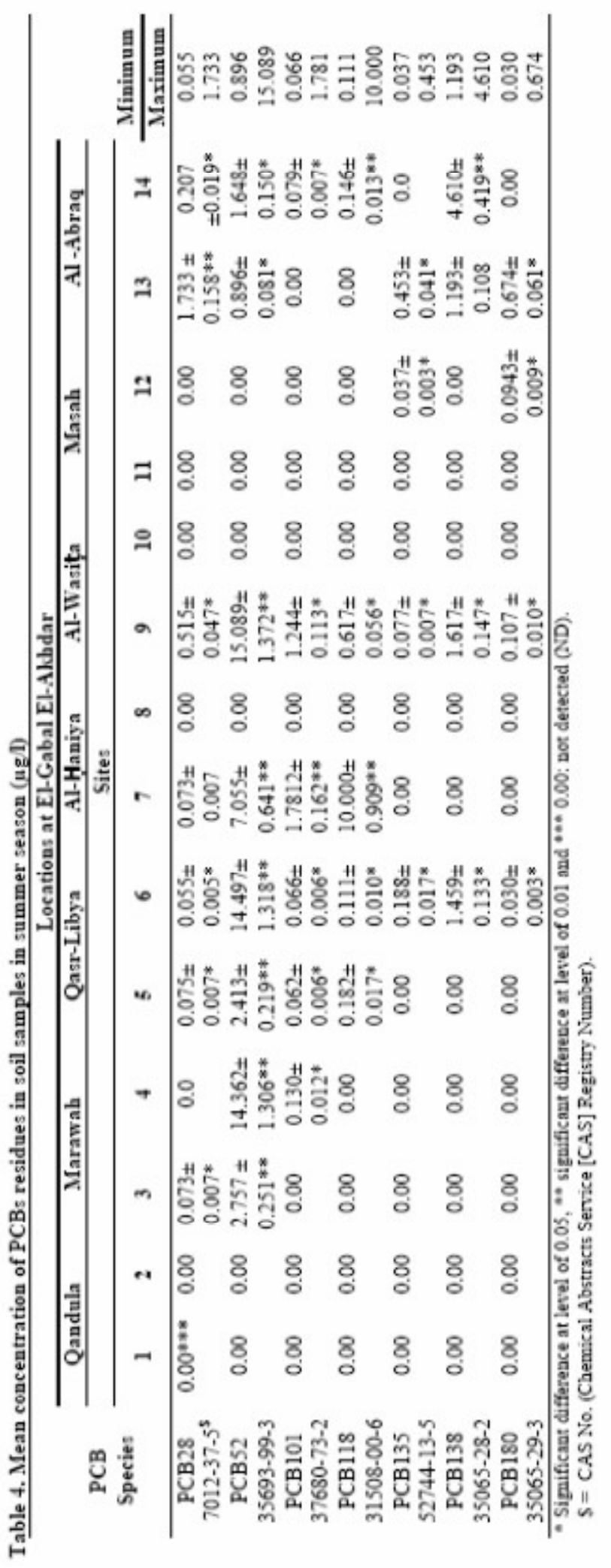




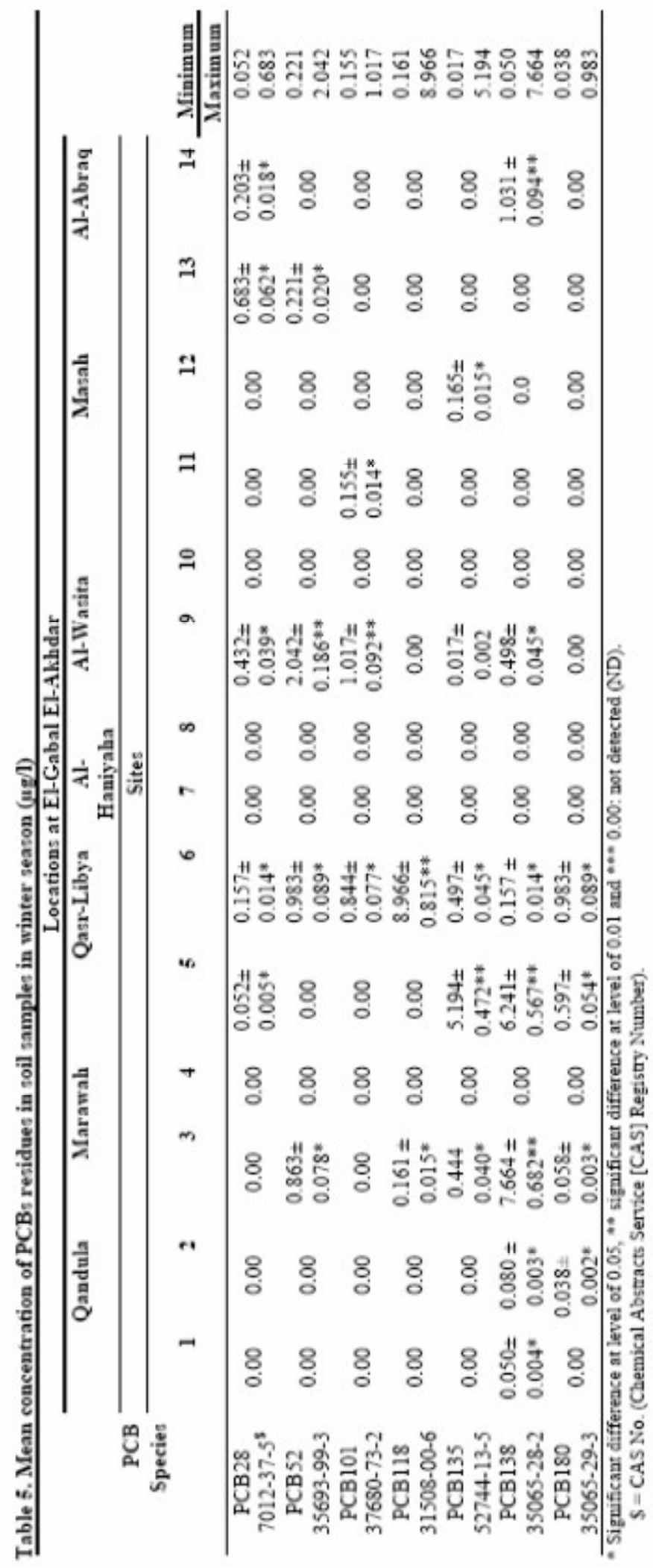




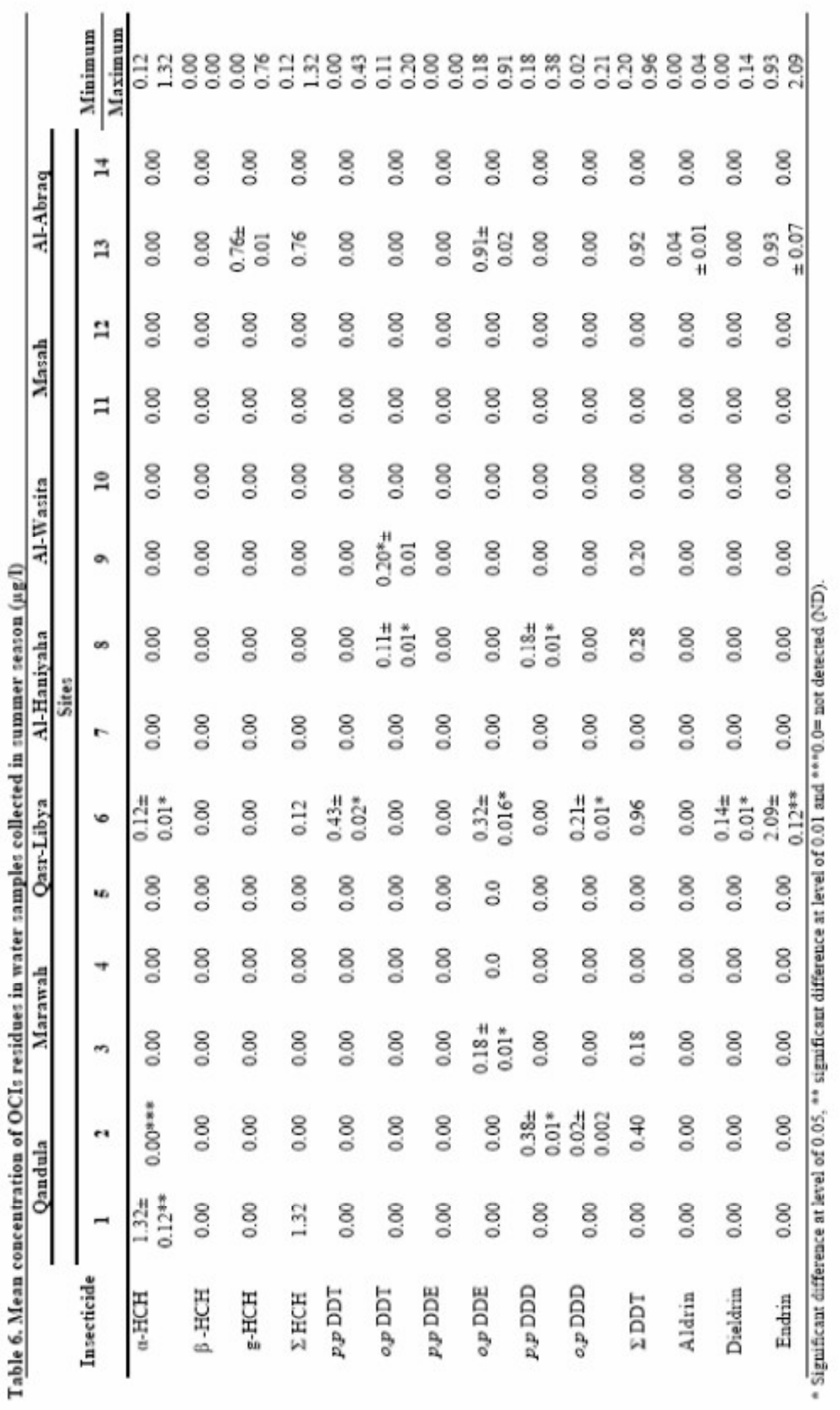




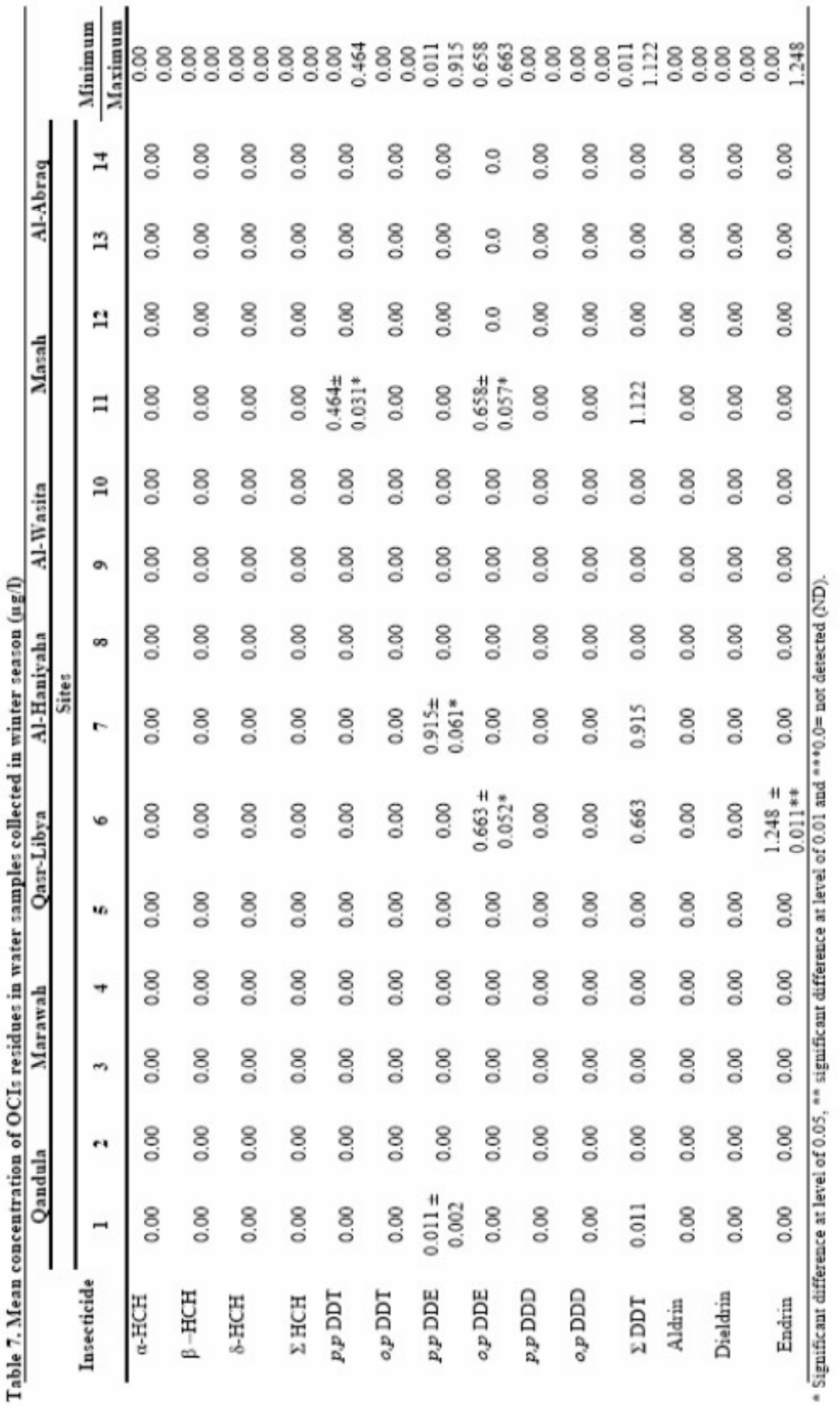




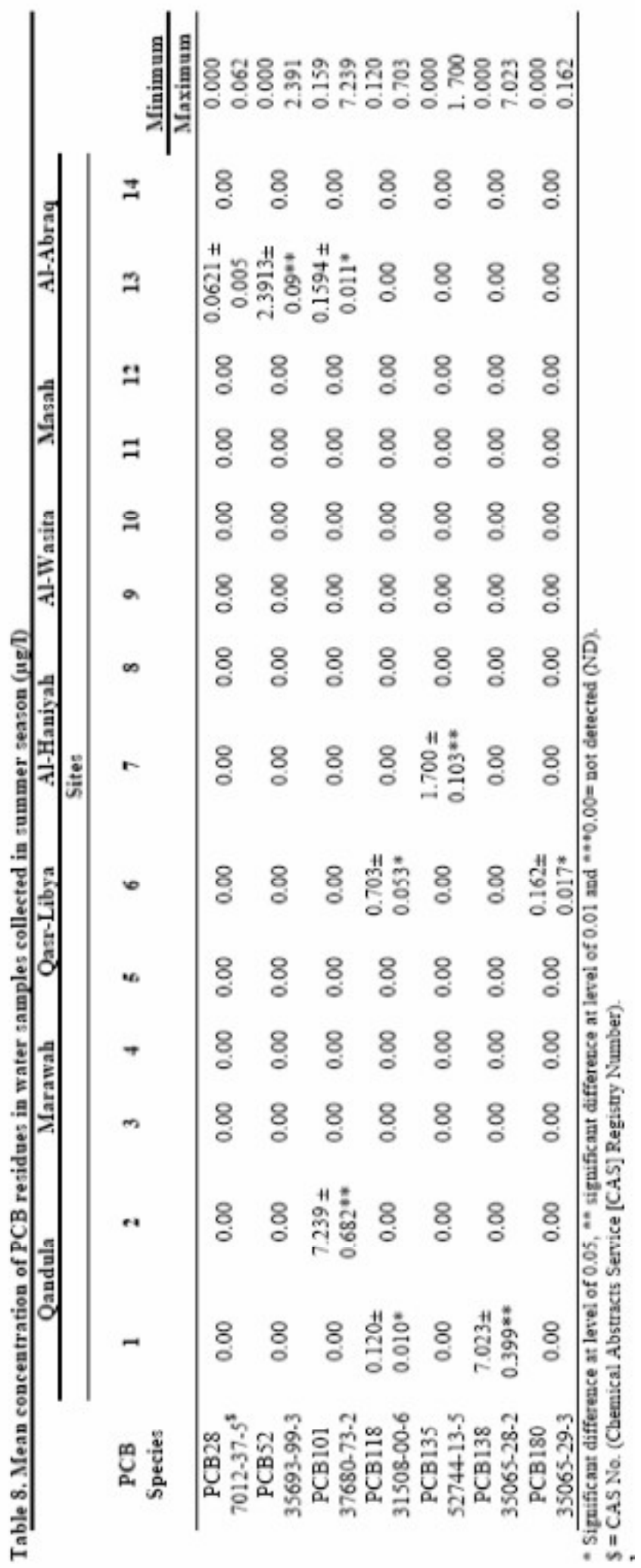




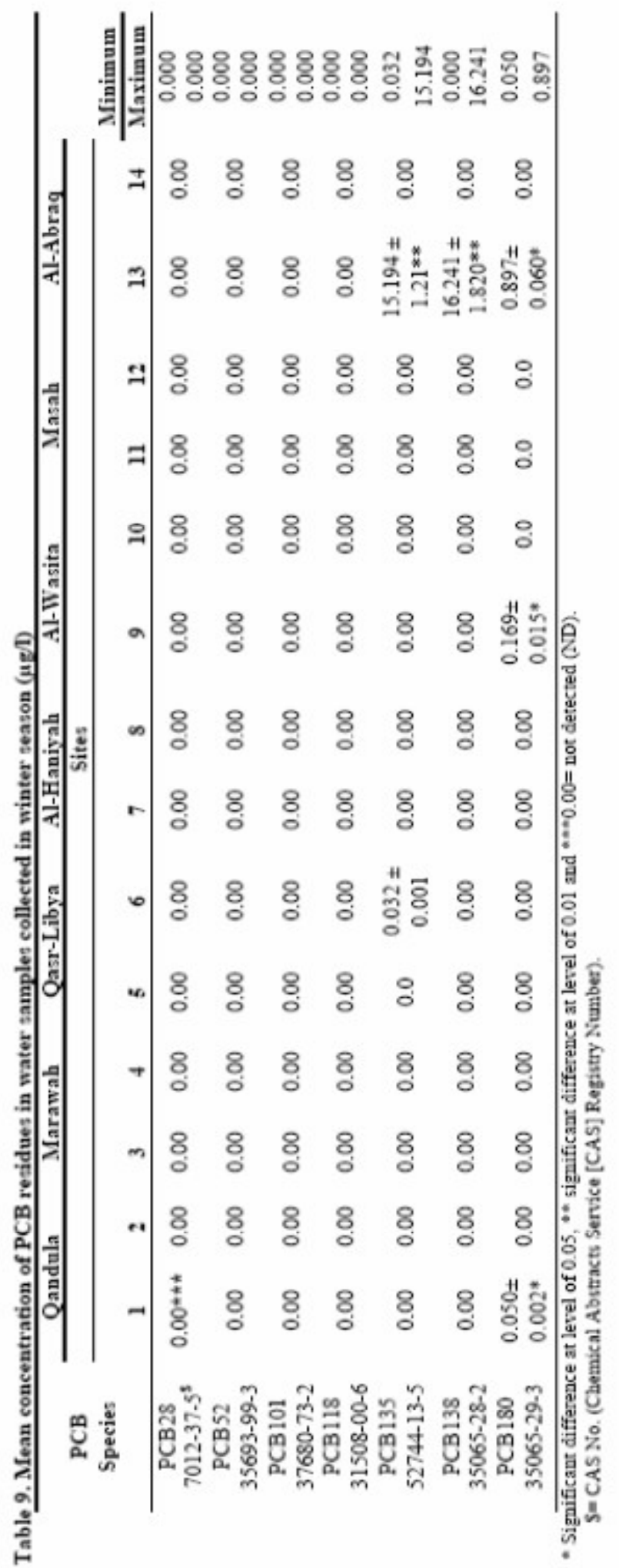


Al-Abraq (site 13) $(0.76 \mu \mathrm{g} / \mathrm{l})$ and Qasr-Libya (site 6) $(0.12 \mu \mathrm{g} / \mathrm{l})$ in summer. $\mathrm{HCH}$ isomers were found in very few locations at low concentrations and that might be due to their differences in physicochemical and biological properties, where they having higher vapor pressure (Tang et al., 2007). In winter, the collected water samples appeared to have no residue of the all detected OCIs.

\section{DDT family (metabolites)}

The results showed the existence of a small numbers of DDT isomers (metabolites) in water samples collected in summer (Table 6). The higher total (sum) concentration of DDT isomers and family ( $\Sigma$ DDT) $(0.96$ and $0.92 \mu \mathrm{g} / \mathrm{l})$ were detected in Qasr-Libya (site 6) and Al-Abraq (site 13), respectively (Table 6). The products of DDT or its metabolites were found in few locations. Water samples analysis in winter showed that there were only four sites that have been found to contain members of DDT isomers (site 1, 6, 7 and 11) (Table 7).

The present investigation showed that both isomers of $\operatorname{DDE}(p, p$ and $o, p)$ were the most common residues among the other isomers of DDT which could be an indication of less tendency of recent exposure to new sources of DDT and the lower accumulation of residues was probably accumulated through indirect sources such as long range transport or historical application (Hong et al., 1999; Zhang et al., 2003). This also might be an evidence of the usage of DDT in El-Gabal ElAkhdar area, long time ago because DDT metabolites (especially DDE) were detected at lower concentrations at certain sites that water samples have been collected from. The other reason might be that DDE has transported better in the atmosphere than other forms (Poolpak et al., 2008; Zhou, 2008).

\section{Aldrin, dieldrin and endrin}

The results indicated the presence of a low concentration of aldrin in water samples that have been collected in summer in the location of Al-Abraq (site 13 only) $(0.0373 \mu \mathrm{g} / \mathrm{l})$ (Table 6$)$. Also, one site only was found to contain dieldrin (site 6) in Qasr-Libya location with a concentration of $0.140 \mu \mathrm{g} / \mathrm{l}$. Moreover, endrin was the only compound among these three detected compounds (aldrin, dieldrin and endrin) detected in quantifiable amount $(2.09 \mu \mathrm{g} / \mathrm{l})$ in water samples collected from Qasr-Libya (site 6) during summer season.

For those samples collected during winter season, the residue level of endrin $(1.248 \mu \mathrm{g} / \mathrm{l})$ was the only detected one among the rest of the inspected residues (Table 7). It could be concluded that water samples collected during summer season contained high levels of OCIs than those collected in winter season. The residues of endrin were found in high levels in both samples of summer $(2.09 \mu \mathrm{g} / \mathrm{l})$ and winter $(1.25 \mu \mathrm{g} / \mathrm{l})$ as compared with the other all OCIs inspected at El-Gabal El-Akhdar, Libya. Meanwhile, $o, p$ DDE $(0.9155 \mu \mathrm{g} / \mathrm{l})$ and $\alpha \mathrm{HCH}(1.3230 \mu \mathrm{g} / \mathrm{l})$ were detected at high concentrations during winter season in water samples.

The present study showed that the residues of aldrin, dieldrin and endrin are rarely present in irrigation groundwater but a little residues leaching from soils might be occurred.

\section{PCBs species}

The results of the detected residues of PCBs of summer and winter samples are presented in the Tables 8 and 9, in respect. There were significant variations in PCB compounds for both seasons of summer and winter. PCB52 was detected in site 13, PCB101 (site2), PCB135 (site7) and PCB138 (site 1) which showed a highly significant increase $(\mathrm{p} \leq 0.01)$ in water samples collected in summer. Meanwhile, results showed significant increase $(\mathrm{p} \leq 0.01)$ in PCB135 and PCB138 as they were detected in site 13 .

In winter, the results indicated that the highest concentration of PCB species was detected in water samples collected in summer and was found in Qandula location (site 2) $(\mathrm{PCB} 101=7.239 \mu \mathrm{g} / \mathrm{l})$, while the lowest mean of concentration was presented in the location of Al-Abraq (site 13) where PCB 28 reached a concentration of $0.062 \mu \mathrm{g} / \mathrm{l}$ (Table 8 ).

The results of the laboratory analysis of water samples collected in winter showed that Al-Abraq location contains the highest number of PCB species (PCB 135, PCB 138, PCB 180) at site 13 and the highest mean concentration was found in the same area ( PCB $138=16.241 \mu \mathrm{g} / \mathrm{l}$ ) as shown in Table 9. The presented results showed that concentration of $\mathrm{PCBs}$ in water were low and these results are similar to those obtained by Yu et al. (2014).

\section{REFERENCES}

Afful, S., A. Anim and Y. Serfor-Armah. 2010. Spectrum of organochlorine

pesticide residues in fish samples from the Densu Basin. Res. J. Environ. Earth Sci. 2(3):133-138.

Ayas, Z., N. Barlas and D. Kolankaya. 1997. Determination of organochlorine pesticide residues in various environments and organisms in Goksu Delta, Turkiye. Aquatic Toxicol. $39: 171-181$

Barlas, N. E. 1997. Toxicological assessment of biodegraded malathion in albino mice. Bull. Environ. Contam.Toxicol. 57: 705-712. 
Blaso C., G. Font and Y. Pico. 2005. Analysis of pesticides in fruits by pressurized liquid extraction and liquid chromatography-ion trap-triple stage mass spectrometry. J. Chromat. A 1098: 37-43.

Bouman, H. 2004. South Africa and the Stockholm on Persistent organic pollutants. Afr. J. Sci. 100: 323-328.

Calamari, D. and H. Naeve. 1994. Review of pollution in the African aquatic environment. CIFA Technical paper No. 25. Food and Agriculture Organization of the United Nations, Rome, Italy. 118 p.

Costat software. 1988. Microcomputer Program Analysis. CoHort software, Berkely, CA, USA.

Covaci, A., P. Manirakiza and P. Schepens. 2002. Evaluation of hot Soxhlet extraction for the determination of POPs from soil. Bull. Environ. Contam. Toxicol. 68(1):97- 103.

Covaci, A., A. Gheorgheb, S. Voorspoelsa, J. Maervoeta, E. S. Redekere, R. Blustc and P. Schepensa. 2005. Polybrominated diphenyl ethers, polychlorinated biphenyls and organochlorine pesticides in sediment cores from the Western Scheldt River (Belgium): Analytical Aspects and Depth Profiles. Environ. Int. 31:367-375.

Dubus, I. G., J. M. Hollis and C. D. Brown. 2000. Pesticides in rainfall in Europe. Environ. Pollut. 110: 331-344.

Duc, T. V and S. H. Viet. 2013. Residue and temporal trend of polychlorinatedpiphenyls (PCBs) in surface soils from Bacninh, Vietnam. Int.J. Environ. Chem. Ecol. Geol. Geophs. Engin. 7(7):418 - 421.

El-Bouraie, M. M., A. A. El Barbary and M. Yehia. 2011. Determination of organochlorine pesticide (OCPs) in shallow observation wells from El-Rahawy contaminated area, Egypt. Aplinkostyrimai Inžinerijairvadyba. 57(3):2838.

Fox, G. A., B. Collins, E. Hayakawa, D.V. Weseloh, J. P. Ludwig, T. J. Kubiak and T. C. Erdman. 1991. Reproductive outcomes in colonial fish-eating birds: A biomarker for developmental toxicants in Great Lakes food chains. J. Great Lakes Res. 17:158-167.

Golfinopoulos, S. K., A. D. Nikolaou, M. N. Kostopoulou, N. K. Xilourgidis, M. C. Vagi and D. T. Lekkas. 2003. Organochlorine pesticides in the surface waters of Northern Greece. Chemosphere. 50: 507-516.

Hassan, J., P. N. Manavi and E. Darabi. 2013. Polychlorinated biphenyls hot and cold seasons distribution in sea water, sediment, and fish samples in the Khour-e-Mousa (MahShahr), Iran. Chemosphere. 90(9):2477-82.

Hellwell, M. J. 1988. Toxic substances in rivers and streams. Environ. Poll. 50(1-2):61-85.

Hong, H., W. Chen, L. Xu, X. Wang and L. Zhang. 1999. Distribution and fate of organochlorine pollutants in the Pearl River Estuary. Mar. Poll. Bull. 39:376-382.

Hooper, K., M. X. Petreas, J. She, P. Visita, J. Winkler, M. McKinney, M. Mok, J. Garcha, M. Gill, R. D. Stephens, G. Semenova, T. Sharmanov and K. Chuvakova. 1997. Analysis of breast milk to assess exposure to chlorinated contaminants in Kazakstan: PCBs and organochlorine pesticides in Southern Kazakstan, Environ. Health
Perspec. 105:1250-1254.

Kanatharana, P., S. Bunvunno and B. Kaewnarong. 1994. Organo-chlorine pesticide residues in Songkhla Lake. Environ. Mon. Assess. 33: 43-52.

Kocan, R.M. and M.L. Landolt. 1989. Survival and growth to reproductive maturity of Coho salmon following embronic exposure to a model toxicant. Mar. Environ. Res. 27: 177193.

Leong, K. H., T. L. L. Benjamin and M.A. Mustafa. 2007. Contamination levels of selected organochlorine and organophosphorous pesticide residues in the Selangor River, Malaysia between 2002 to 2003. Chemosphere. 66:1153-1159.

Mahugija, J. A., B. Henkelmann and K. W. Schramm. 2014. Levels, compositions and distributions of organochlorine pesticide residues in soil 5-14 years after clean-up of former storage sites in Tanzania. Chemosphere. 117:330337.

Mawussi, G. 2008. Bilanenvironnemental de l'utilisation de pesticides organochlorésdans les cultures de coton, café et cacao au Togo et recherched'alternatives par l'évaluation du pouvoir insecticide d'extraits de plantes locales contre le scolyte du café ((Hypothenemus hampei (Ferrari)). Thèse de doctorat. Université de Toulouse, France. pp207.

Montenegro, S., M. Lacayo, F. Plcado and Z. Aloep. 1998. Organochlorine pesticides in sediment and biological samples from the coastal lagoons of Nicaragua.FAO/IAEA. p 29-40.

Owusu-Boateng, G. and K. K. Amuzu. 2013. Levels of organochlorine pesticides residue in cabbage cultivated in farms along River Oyansia, Accra-Ghana. Am. J. Sci. Ind. Res. 4:489-498.

Patton, G. W., M. D. Walla, T. F. Bidleman and L. A.Barrie. 1991. Polycyclic aromatic and organochlorine compounds in the atmosphere of northern Ellesmere Island, Canada. J. Geophys. Res. 96: 10867-10877.

Pawlak, Janet F. and Maria Laamanen. 2010. Hazardous substances in the Baltic sea - An integrated thematic assessment of hazardous substances in the Baltic Sea, Environ. Proc. No. 120A. Published by the Baltic Marine Environment Protection Commission-Helsinki Commission, Finland.

Podlesakova. E. , J. Nemecek and R. Vacha. 1997.Contamination of soil with persistent organic xenobiotic substances in the Czech Republic. Rostl. Vyr. 43(8):357.

Poolpak, T., P. P. Okethitiyook, M. Kruatrachue, U. Arjarasirikoon and N. Thanwaniwat. 2008. Residue analysis of organochlorine pesticides in the Mae Klong river of Central Thailand. J. Hazard Mater. 156:230-239.

Salem, D. M. S. A., A. El Sikaily and A. El Nemr. 2014. Organocholorines and their risk in marine shellfish collected from the Mediterranean coast, Egypt. Egypt. J. Aquat. Res. 40:93-101.

Shivani, J. G., S. Bikram and S. Adarsh. 2012. Quinalphos behavior in tea soil. Int. J. Environ. Sci. 3(3): 1177-1184. 
Solomon, A. 2016. Determination of organochlorine pesticide residues in water and sediment samples from selected areas of River Ilaje, Nigeria. Amer. Chem. Sci. J. 11(2):16.

Sporring, S., S. Bowadt, B. Svensmark and E. Bjorklund. 2005. Comprehensive comparison of classic Soxhlet extraction with Soxtec extraction, ultrasonication extraction, supercritical fluid extraction, microwave assisted extraction and accelerated solvent extraction for the determination of polychlorinated biphenyls in soil. J. Chromatogr. A. 1090: 1-9.

Tang, Z. W., Z. F. Yang, Z. Y. Shen, J. F. Niu and R. F. Liao. 2007. Distribution and sources of organochlorine pesticides in sediments from typical catchment of the Yangtze River, China. Arch. Environ. Contam. Toxicol. 53:303-312.

Tasdeminr, Y., G. Alihoglu, N. Salihoglu and A. Zbirgu. 2012. Air-soil exchange of PCBs: Seasonal variations in levels and fluxes with influence of equilibrium conditions. Environ. Poll. 169:90.

UNEP Chemicals. 1999. Guidelines for the Identification of PCBs and Materials Containing PCBs (PDF). United Nations Environment Programme. p. 40. Retrieved 200711-07.

USEPA. 1980. Manual of analytical method for the analysis of pesticide residues in human and environmental samples. United State Environmental Protection Agency.
USEPA. 1996. Guidance for addressing unextracted residues in laboratory studies, Method 3540C. United States Environmental Protection Agency. Washington, DC, USA.

Yi-Fan, L., A. McMillan and M. Trevor Scholtz. 1996. Global $\mathrm{HCH}$ usage in 1o 1o longitude-latitude resolution. Environ. Sci. Technol. 30: 3525-3533.

Yu, Y., Y. Li., Z. Shen, Z. Yang, L. Mob, Y. Kong and I. Lou. 2014. Occurrence and possible sources of pesticides organochlorine and polychlorinated biphenyls (PCBs) along the Chao River, China. Chemosphere.114: 136-143.

Zhang, Z. L., H. S. Hong, J. L. Zhou, J. Huang and G. Yu. 2003. Fate and assessment of persistent organic pollutants in water and sediment from Minjiang River Estuary, Southeast China. Chemosphere. 52:1423-1430.

Zhou, R., L. Zhu and Y. Chen. 2008. Levels and source of organochlorine pesticides in surface waters of Qiantang River, China. Environ. Monit. Assess. 136:277-287.

Zhu, Y. F., H. Liu, Z. Q. Xi, H. X. Cheng and X. B. Xu. 2005. Organochlorine pesticides (DDTs and $\mathrm{HCHs}$ ) in soils from the outskirts of Beijing, China. Chemosphere. 60:770-778. 
الملخص العربي

متبقيات المبيدات الحشرية العضوية الكلورينية والمركبات ثنائية الفينيل عديدة الكلور في عينات الماء والتربة المجمعة من الجبل الأخضر - ليبيا

عبدالفتاح سيد عبدالكريم سعد ، السيد حسن محمد تايب ، ليلى عبدالقتاح محمد ، صلاح محمد إدريس حسن الإنس

وقد تم تقدير منبقيات المبيــدات الحسشرية العـضوية

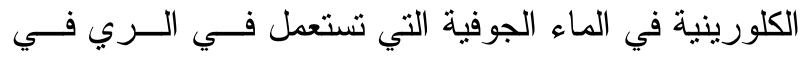

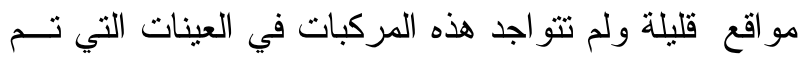

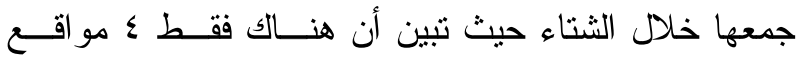

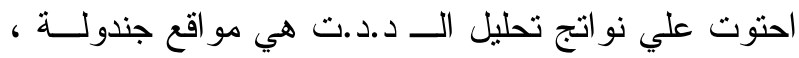

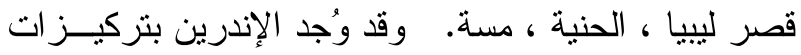

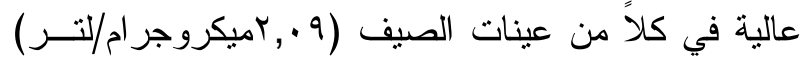

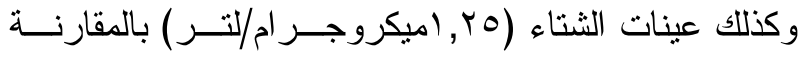
بالمركبات الأخري المقدرة في منطقة الجبل الأخضر • وفي o,p DDE نفس الوقت تم تقدير و الكثف عن تو اجد مركبات aHCH ,

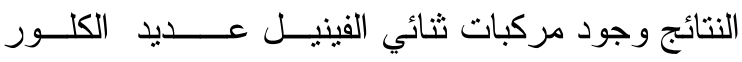
بتركيز ات عالية في المياه الخاصة بفصل الــصيف وكى ودـان

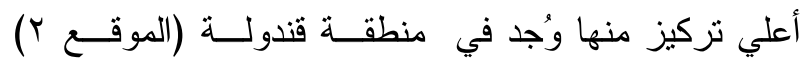

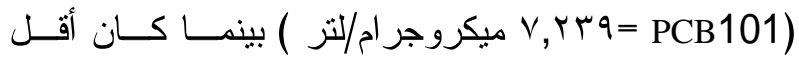
PCB تركيز في منطقة الأبرق (موقع با ا) حيث كان تركيز

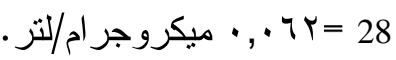

تم تقدير منبقيات المبيدات الحشرية العضوية الكلورينية

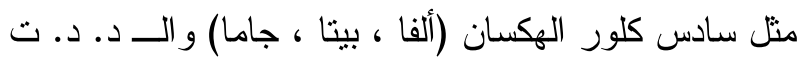
ونواتج تحلله و الألدرين و الديلدرين و الإندرين في عينـات

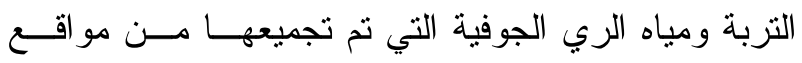

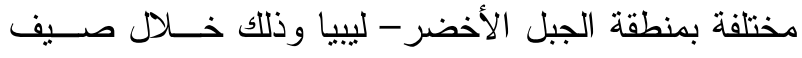

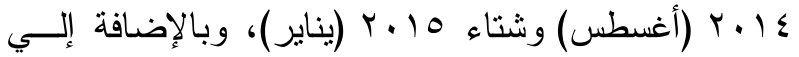
ذللك تم تقدير أنو اع مختلفة من مركبات ثنائي الفينيل عــديد

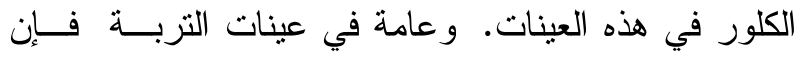
إجمالي تركيزات الـــد.د.ت ونو اتج تحلله التي تم تقديرها

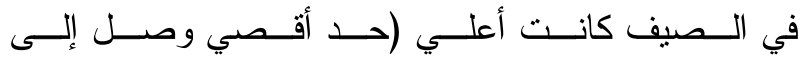

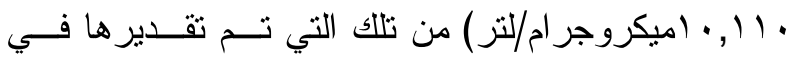

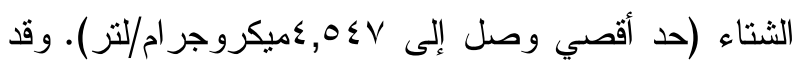

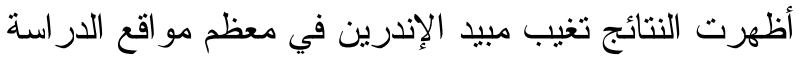
الحالية. كما بينت النتائج أيضاً وجود V أنو اع من مركبات

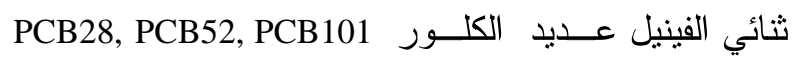
PCB118, PCB135, PCB138, PCB180

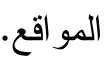

